\title{
Survival of juvenile basin big sagebrush under different grazing regimes
}

\author{
M.K. OWENS AND B.E. NORTON
}

\begin{abstract}
Basin big sagebrush (Artemisia tridentata Nutt ssp tridentata Beetle) often invades rangelands seeded to introduced grass species. Livestock grazing may enhance the invasion but the effects of grazing intensity on invasion rates are not known. To investigate invasion rates, individual big sagebrush plants were marked and observed for mortality over a 4-year period within a short duration grazing (SDG) cell and continuous season-long grazed pastures.

Over the course of the experiment, the survival of juvenile big sagebrush was higher in the SDG cell. However, there were no differences in survival between grazing treatments during the first year of the study. In subsequent years, declining tiller numbers and density of individual crested wheatgrass plants may have decreased the competitive pressure on juvenile big sagebrush under SDG.

The intensity of grazing did not affect which individual juveniles survived. Plants with more than $50 \mathrm{~cm}^{2}$ canopy area had the highest survival rates of all big sagebrush in both grazing treatments. Plant density, which ranged from 1 to 30 plants $\mathrm{m}^{-2}$, did not affect plant survival in either of the grazing treatments. Big sagebrush survival in the SDG cell was higher in a rhizomatous grass community than in a tussock grass community.
\end{abstract}

Keywords: Artemisia tridentata, short duration grazing, crested wheatgrass

Basin big sagebrush (Artemisia tridentata Nutt. ssp. tridentata, Beetle) is a widespread shrub on western rangelands and is the least palatable of the tridentata complex (Beetle and Johnson 1982). Basin big sagebrush is usually found on productive semiarid rangelands and large areas of this vegetation type have been converted to seeded grasslands, usually principally crested wheatgrass [Agropyron desertorum (Fisch.) Schult. and A. cristatum (L.)]. Big sagebrush plants often re-establish in the seedings, however, and reduce grass production in a variety of ecosystems (Frischknecht 1978, Robertson et al. 1970, Hull and Klomp 1966, Gobena 1984). Frischknecht (1978) stated that "reinvasion is a chronic situation requiring periodic control of big sagebrush to maintain production of seeded grasses". However, Marlette and Anderson (1986) found limited big sagebrush invasion in crested wheatgrass stands in southern Idaho. Only when individuals survived the initial treatment or established from residual seeds shortly after the treatment did big sagebrush successfully invade the seeding.

Research emphasis has been directed at the effects of grazing and overgrazing under conventional management systems on big sagebrush/grass communities (Laycock and Conrad 1981, Frischknecht 1978, West et al. 1984, Laycock 1967, Robertson et al. 1970). Most studies concur that spring grazing will increase the amount of big sagebrush in a community, while grazing during fall will decrease big sagebrush under certain conditions. However, these studies did not elucidate the mechanisms involved.

\footnotetext{
Authors are with the Texas A\&M University Research and Extension Center, 1619 Garner Field Road, Uvalde, TX 78801; and Range Science Department, Utah State University, Logan Utah 84322-5230.

This research was supported by the Utah Agricultural Experiment Station, Utah State University, Logan. Utah 84322-4845. Approved as journal paper no. 3704 . Manuscript accepted 27 April 1989.
}

The objectives of this study were to determine the effect of grazing intensity on juvenile big sagebrush survival. The interactions of grazing intensity, plant size, plant density, and neighboring grass species on big sagebrush survival were investigated.

\section{Study Area and Methods}

The study was conducted at the Tintic Research Station in central Utah $\left(39^{\circ} 53^{\prime} \mathrm{N}\right.$ and $122^{\circ} 03^{\prime} \mathrm{W}$, elevation $\left.1,830 \mathrm{~m}\right)$. The area is typical of foothill rangeland in the Great Basin. Mean annual precipitation, based on a 23-year record, was $374 \mathrm{~mm}$. The 2 dominant soils within the study area were a Xerollic Calciorthid with a sandy loam texture and a Torrifluventic Haploxeroll, which has a coarse loamy texture.

Big sagebrush survival was estimated in 2 sets of pastures where native vegetation had been removed and introduced grasses planted in the early 1950s. The first set (Pasture 3 and 19) was seeded with crested wheatgrass and grazed according to the traditional, season-long grazing system of $\mathbf{3 0}$ animal units on $\mathbf{2 8}$ ha for 90 days.

The 84 ha in the second set of pastures consisted of 10 equalsized paddocks radially arranged to form a SDG cell. Before 1983, the area had been managed as 3 separate pastures in a similar manner as Pastures 3 and 19. One-third of the area was seeded to intermediate wheatgrass [Thinopyrum intermedium (Host), Barker D.R. Dewey], one-third was seeded to crested wheatgrass, and the remaining third was seeded to a mixture of the 2 grasses mentioned above and tall wheatgrass [T. ponticum (Podp.), Barker and D.R. Dewey]. The mixture has reverted to a crested wheatgrass stand with tall wheatgrass plants sparsely distributed. Only the areas with crested wheatgrass were used to analyze the effect of grazing intensity on big sagebrush survival. Initially, 90 replacement heifers were rotated 3 times through the paddocks on a 3-day grazing cycle. The same grazing system was used for the following 3 grazing seasons except that the rotation changed to 2-days in each paddock in 1985 and 1986. The grazing season began in early- to mid-May.

Thirty-four permanent plots $(3.5 \times 4 \mathrm{~m})$ were established during the spring of 1983 in the short duration grazing cell to allow monitoring of big sagebrush populations. Eleven plots were established in pastures grazed season long. Plots were randomly located after the pastures were stratified to eliminate areas without big sagebrush. Establishment, photography, and mapping procedures have been described previously (Owens et al. 1985). Sample sizes of individual big sagebrush plants and the grass species in each treatment are presented in Table 1. Each plot was sampled and mortality recorded each spring and fall between May 1983 and May 1986. Juvenile big sagebrush were identified as plants greater than 1 year old but without evidence of any reproductive stalks. A plant enters the adult phase of the life cycle after producing seed. No new recruitment was detected in the permanent plots.

\section{Data Analysis}

The pattern of survival was tested using maximum likelihood 
Table 1. Sample size of basin big sagebrush juveniles and grass species within each treatment.

\begin{tabular}{lccl}
\hline \hline Treatment & Paddock & Sample size & Grass species ${ }^{1}$ \\
\hline Season-long & 3 & 1029 & Agde \\
grazing & 19 & 532 & Agde \\
Short duration & 1 & 744 & Agde/ Thin \\
grazing & 2 & 94 & Agde \\
& 3 & 226 & Agde \\
& 4 & 272 & Agde \\
& 5 & 138 & Agde \\
& 6 & 180 & Agde \\
& 7 & 1007 & Thin/Agde \\
& 8 & 671 & Thin \\
& 9 & 97 & Thin \\
& 10 & 79 & Thin/Agde \\
\hline
\end{tabular}

'Agde = Agropyron desertorum $;$ Thin $=$ Thinopyrum intermedium .

analysis and the multinomial distribution (White 1983). Individual plants, which were the experimental unit, were observed for mortality at each sample date. In each treatment, 1 of 7 outcomes was possible for every plant. The individual could have died at any of the 6 observation times or have survived the entire experiment. The count of dead juveniles within each time period and treatment constitute a multinomial sample. Survival rates and associated standard errors were estimated for the finite time periods using the FORTRAN program SURVIV (White 1983).

Hypotheses are tested by constructing models which assume equal survival rates for specified time periods. The model is then tested using a Chi-square test where the predicted survival rates are the expected values and the actual data are observed values. To test for grazing intensity effects, big sagebrush survival rates from the SDG cell and the CSLG plant populations were set equal for the grazing period while survival rates for other periods were allowed to vary. If the Chi-square value was greater than the critical value at alpha $=0.05$, then the model assuming equal survival during grazing periods was rejected. If 2 or more models were not rejected using a Chi-square contingency test, the best model was selected using a log-likelihood ratio test. The models must be constructed in a hierarchial manner for this test to be valid. The general form of this test has been described elsewhere (Brownie et al. 1978, White 1983, Gardiner 1984).

\section{Results and Discussion}

\section{Grazing Intensity}

The probability of survival for juvenile big sagebrush differed in the 2 grazing treatments (Table $2 ; X^{2}=114.3$, $\mathrm{df}=6, P<0.001$ ). Individuals in the grazing cell had equal or higher survival rates than plants in the continuous season-long grazed pastures in all but one instance. During the summer of 1984 (between May and
October), mortality was higher than expected in the SDG cell when 95 individuals died and only 56 were expected to die under the model of equality. Most of the difference in survival between the 2 grazing treatments occurred during the summer periods which included the actual grazing times $\left(X^{2}=71.6\right.$, df $\left.=3, P<0.001\right)$. Overwinter survival was not equal between the 2 groups of big sagebrush, however, with survival being higher in the grazing cell.

The mortality in the continuous season-long grazed pastures was not the result of high mortality in a single plot. Pastures 3 and 19 were on the south and north sides of the grazing cell, respectively, and the observed big sagebrush mortality was evenly distributed between these 2 pastures. The low mortality generally experienced within the SDG cell could be due to defoliation patterns and tiller replacement of crested wheatgrass tussocks. Bunchgrass integrity was reduced if a plant was grazed after tiller elongation and the apical meristem was removed (Olson 1988). On heavily defoliated plants, grazed tillers were not always replaced and the bunchgrass began to break apart and spread. Thus, the segmented grass plants might be less competitive or exert less of an influence on individual big sagebrush plants. Big sagebrush survival could then be higher than in an area where crested wheatgrass had been defoliated. The observation that big sagebrush survival was not different between these grazing systems the first summer season after implementation of the short duration grazing cell, suggests that crested wheatgrass plants in these pastures initially had similar competitive abilities. Big sagebrush mortality started to vary between the 2 treatments during the first winter following intense grazing. The differences persisted for the remainder of the study.

A very intense, localized thunderstorm occurred during July 1984 and a great deal of litter buried 2 plots. The increase in mortality during the summer of 1984 was concentrated in those plots and appeared to be a result of litter deposition during the storm rather than grazing.

Several other studies have reported the effects of grazing intensity on survival rates of perennial shrubs. Grazing increased the survival rate of thornbush (mostly Acacia spp.), which is unpalatable, growing in a savanna in eastern Botswana (van Vegten 1984). Crisp (1978) investigated the relationship of grazing intensity and shrub survival and found that heavy grazing caused saltbush (Atriplex vesicaria) populations to decline while intermittent grazing caused the populations to increase in Australia.

Big sagebrush, which varies in palatability depending on the species and subspecies, is killed under some grazing conditions. In a separate study at Tintic, Yabann (1984) found that big sagebrush consumption by domestic sheep was correlated with monoterpenoid concentrations and the time of year. Big sagebrush contributed a larger portion of the total diet during the fall than in the summer. Frischknecht and Harris (1973) reported that fall grazing by sheep killed big sagebrush if density was less than 1.4 plants $\mathrm{m}^{-2}$.

Table 2. Observed deaths and estimated survival rates of juvenile basin big sagebrush in 2 grazing treatments.

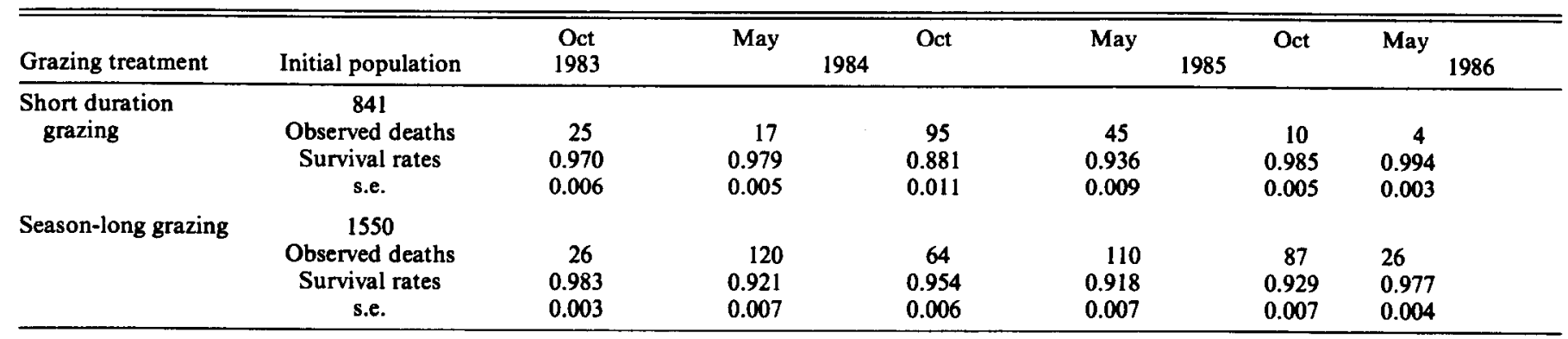


Survival in a Tussock Versus Rhizomatous Grass Stand

There were 2 distinct grass communities in the SDG cell; crested wheatgrass was the dominant grass species in two-thirds of the SDG cell while intermediate wheatgrass was prevalent in the remaining third. There were no significant differences in big sagebrush survival between grass communities during the first year. In subsequent years, survival rates for juvenile big sagebrush with intermediate wheatgrass neighbors were generally higher than for plants having crested wheatgrass neighbors (Figure 1; $X^{2}=148.7$, $\mathrm{df}=6, P<0.001$ ). Only 338 of 2,381 juvenile big sagebrush plants

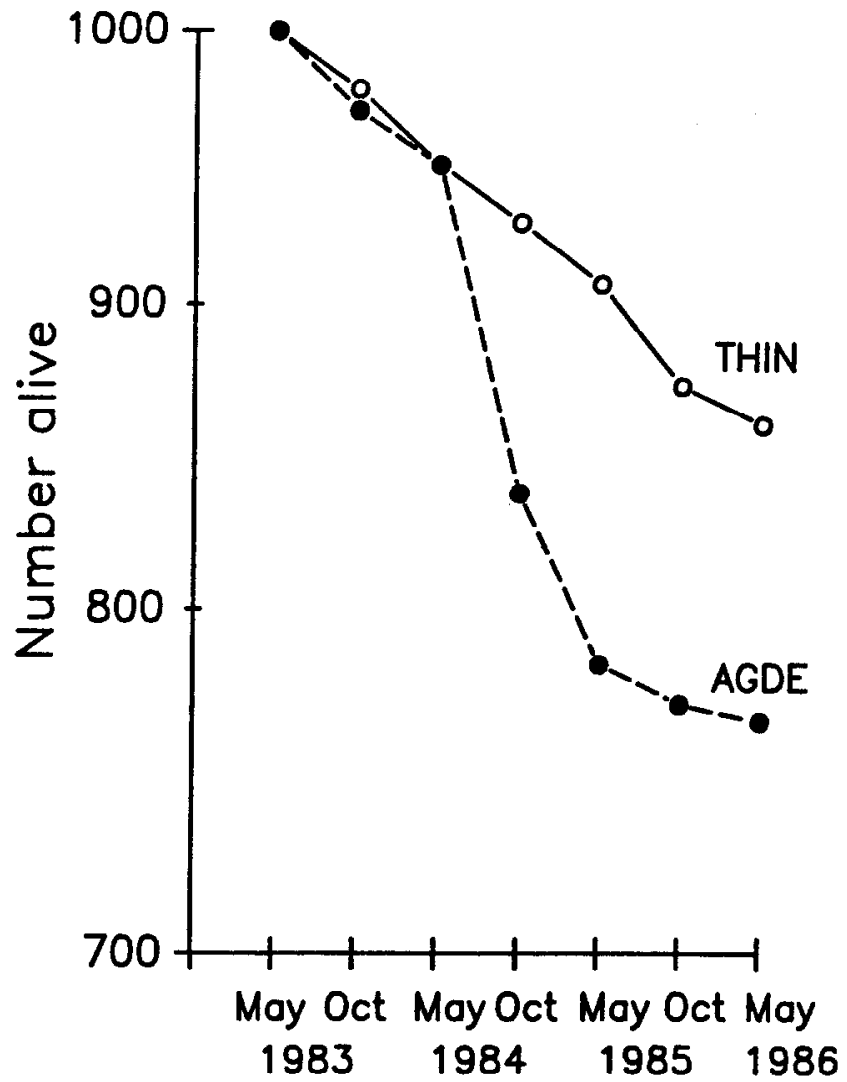

Fig. 1. Survivorship curves for juvenile basin big sagebrush in intermediate wheatgrass (Thinopyrum intermedium; Thin) and crested wheatgrass (Agropyron desertorum; Agde) communities.

died in the intermediate wheatgrass area, while the number of observed deaths (196 of 841) was proportionately higher in the crested wheatgrass area.

Although most of the difference in mortality could be attributed to heavy big sagebrush mortality within the crested wheatgrass stand during the summer of 1984 , survival was generally higher in the intermediate wheatgrass stands. The annual precipitation at this site may not be adequate for intermediate wheatgrass. Indeed, most of the intermediate wheatgrass seeded into other pastures did not persist. The resulting sparse stand of rhizomatous grass may not have exerted much competitive influence on the big sagebrush.

\section{Shrub Density}

The density of big sagebrush, in crested wheatgrass stands and in several other tussock grass communities, has no effect on plant survival (Owens and Norton 1989), but it is not known whether big sagebrush density influences juvenile survival in intermediate wheatgrass stands. Three classes of plots were categorized according to big sagebrush density: sparse (fewer than 6.5 plants $\mathrm{m}^{-2}$ ); medium (between 10.6 and 13 plants $\mathrm{m}^{-2}$ ); and dense (more than 16 plants $\mathrm{m}^{-2}$ ). Juvenile big sagebrush survival did not vary signifi- cantly between these 3 density cohorts $\left(X^{2}=15.9, \mathrm{df}=11, P=\right.$ 0.102).

Plant survival was not affected by cohort density within a plot for the range of 1 to 30 big sagebrush plants $\mathrm{m}^{-2}$ found in the grazing cell. Balph and Malechek (1985) found cattle avoided stepping on grass tussocks if possible and that increasing animal density did not increase the likelihood that a tussock would be trampled. Thus, the survival of plants that are discrete individuals rather than a homogeneous sward does not seem to be affected by trampling as stock density increases.

\section{Plant Size and Grazing Effects on Juvenile Survival}

Plant size classes were established using natural groupings in the frequency histogram of canopy area. Plants were categorized as small (canopy area less than $50 \mathrm{~cm}^{2}$ ); medium (between 50 and 175 $\mathrm{cm}^{2}$ ); and large (greater than $175 \mathrm{~cm}^{2}$ ). None of the 161 large plants within the SDG cell died. Plants in the medium size class also experienced very low mortality, only 9 of the 218 plants marked died. Survival was significantly lower in the small size class within the SDG cell than in the medium or large cohorts (Figure 2; $X^{2}=$ $47.7, \mathrm{df}=6, P<0.001$ ). Of the 643 small plants marked, 111 died during the 3 year study.

Each size cohort was observed for differential effects on plant survival of short duration grazing as compared to continuous season-long grazing. The distribution of the 3 size classes was

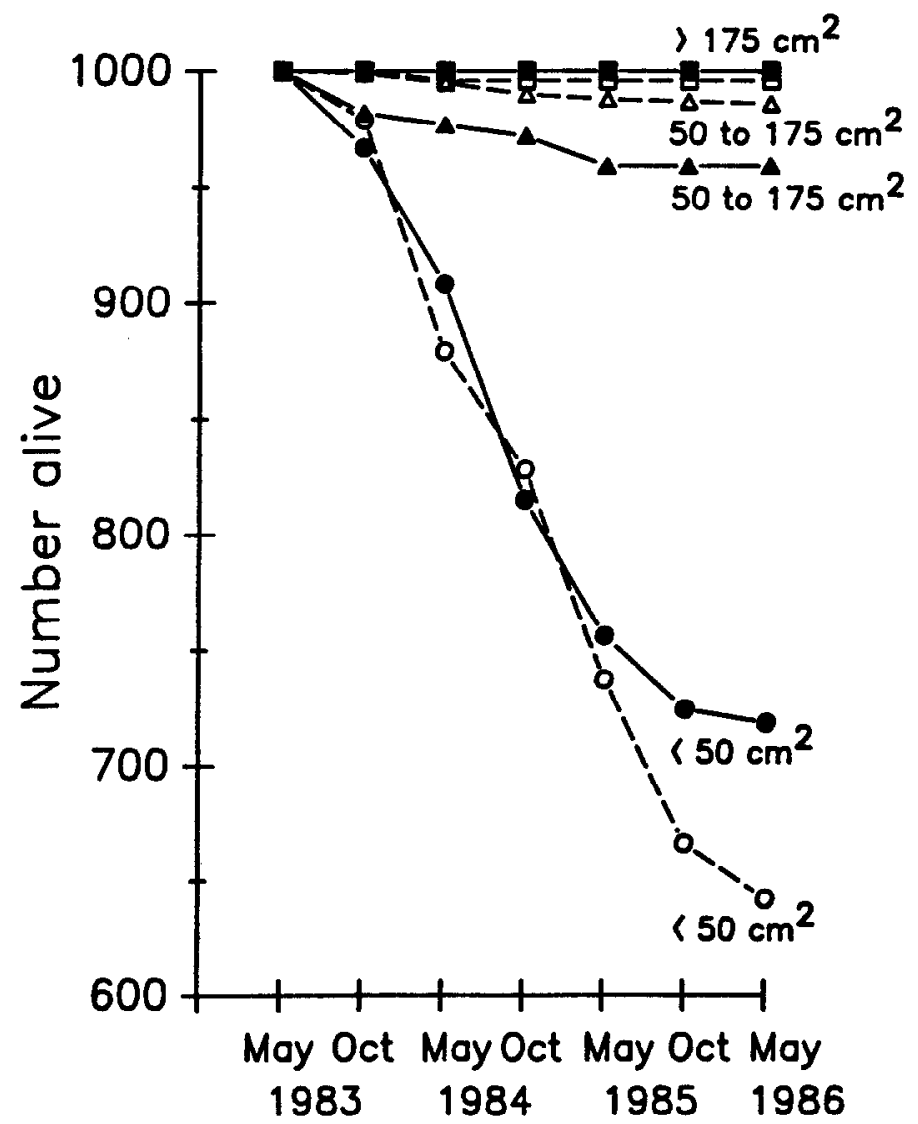

Fig. 2. Survivorship curves for juvenile basin big sagebrush canopy classes in a short duration grazing cell (solid lines) and in a continuous seasonlong grazed (dashed lines) pasture.

similar between the treatments. Too few large plants died to allow rigorous testing of survival rates. The pattern of deaths in the medium-size class was also too sparse to allow testing over the 
course of the study; however at the end of the study, there was no difference in overall survival based on a $X^{2}$ contingency test. For the small juveniles, the pattern and intensity of observed deaths were different between grazing treatments $\left(X^{2}=93.4\right.$, df $=6$, $P<0.001)$. Mortality was greater in the continuously grazed pastures than in the SDG cell for all the time periods except the summer of 1984.

\section{Conclusions}

A better understanding of big sagebrush population dynamics will help understand how big sagebrush reacts to management practices and what this means to future species composition of the community. A small shift in annual survival rates from 0.90 to 0.95 can have large repercussions in community composition. Using a stable age distribution, mean life span will increase from 9.5 to 19.5 years (Pianka 1974). More small shrubs would pass into the medium and large size categories where survival rates were extremely high. More plants would then pass into the adult phase of the life cycle and total seed production would increase. Under these circumstances, the plant community would quickly become dominated by shrubs.

\section{Literature Cited}

Balph, D.F. and J.C. Malechek. 1985. Cattle trampling of crested wheatgrass under short-duration grazing. J. Range Manage. 38:225-227.

Beetle, A.A., and K.L. Johnson. 1982. Sagebrush in Wyoming. Univ. Wyoming Agr. Exp. Sta. Bull. 799.

Brownie, C., D.R. Anderson, K.P. Burnham, and D.S. Robson. 1978. Statistical inference for band recovery data-a handbook. USDI Fish and Wildl. Service Resource Pub. 131. Washington, D.C.

Crisp, M.D. 1978. Demography and survival under grazing of three Australian semi-desert shrubs. Oikos 30:520-528.

Frischknecht, N.C. 1978. Biological methods: A tool for sagebrush management. In: Sagebrush Ecosystem: A Symposium. Utah State Univ., Logan.
Frischknecht, N.C., and L.E. Harris. 1973. Sheep can control crested wheatgrass sagebrush on seeded range if-. Utah Science, March 1973, 27-30.

Gardiner, H.G. 1984. Dynamics of arid land, perennial plant populations with an examination of potential causal agent. Ph.D. Diss., Utah State Univ., Logan.

Gobena, A. 1984. Influence of sagebrush (Artemisia tridentata) invasion on crested wheatgrass (Agropyron desertorum) production and its detection by landsat imagery. M.S. Thesis, Utah State Univ., Logan.

Hull, A.C., and G.J. Klomp. 1966. Longevity of crested wheatgrass in the sagebrush-grass type in southern Idaho. J. Range Manage. 19:5-11.

Laycock, W.A. 1967. How heavy grazing and protection affect sagebrushgrass ranges. J. Range Manage. 20:206-213.

Laycock, W.A., and P.W. Conrad. 1981. Responses of vegetation and cattle to various systems of grazing on seeded and native mountain rangelands in eastern Utah. J. Range Manage. 34:52-56.

Marlette, G.M., and J.E. Anderson. 1986. Seed banks and propagule dispersal in crested wheatgrass stands. J. Appl. Ecol. 23:161-175.

Olson, B.E. 1988. Annual replacement of the tillers of Agropyron desertorum following grazing. Oecologia 76:1-6.

Owens, M.K., H.G. Gardiner, and B.E. Norton. 1985. A photographic technique for repeated mapping of rangeland plant populations in permanent plots. J. Range Manage. 38:231-232.

Owens, M.K., and B.E. Norton. 1989. Survival of juvenile big sagebrush (Artemisia tridentata), a semiarid land shrub, in relation to environmental factors and neighboring plants. Vegetatio (82:155-166).

Pianks, E. 1974. Evolutionary Ecology. Harper and Row, New York.

Robertson, J.H., D.L. Neal, R. McAdams, and P.T. Tueller. 1970. Changes in crested wheatgrass ranges under different grazing treatments. J. Range Manage. 23:27-34.

West, N.E., F.D. Provenza, P.S. Johnson, and M.K. Owens. 1984. Vegetation change after 13 years of livestock grazing exclusion on sagebrush semidesert in west central Utah. J. Range Manage. 37:262-264.

White, G.C. 1983. Numerical estimation of survival rates from bandrecovery and biotelemetry data. J. Wildl. Manage. 47:716-728.

Yabann, W.K. 1984. Plant monoterpenoids as factors in diet selection and grazing behavior of sheep. M.S. Thesis. Utah State Univ., Logan. 